\title{
A note on the effects of selected prebiotics on the performance and ileal microbiota of broiler chickens
}

\author{
D. Józefiak ${ }^{1}$, S. Kaczmarek and A. Rutkowski \\ Poznań University of Life Sciences, Department of Animal Nutrition and Feed Management \\ Wotyńska 33, 60-637 Poznań, Poland
}

(Received 7 August 2007; revised version 14 April 2008; accepted 24 June 2008)

\begin{abstract}
The objective of the experiment was to study the influence of lactose, inulin, and modified $\beta$-glucan as additives to maize-based diets on the performance of broiler chickens, as well as on the $\mathrm{pH}$ in the crop, gizzard, ileum, caeca and on populations of selected ileal microflora species. Over the entire experimental period (day 1 - day 42), the animals (384 male broilers, 4 treatments, 12 replicates of 8 birds per treatment) were offered maize-based diets. The diets were fed either without any supplementation (control diet), or with a supplement of either $0.025 \%$ modified $\beta$-glucan, $0.3 \%$ inulin, or $0.2 \%$ purified lactose. Body weight gain decreased $(\mathrm{P}<0.05)$ and feed conversion ratio worsened $(\mathrm{P}<0.05)$ in birds fed diets with supplements in comparison with the nonsupplemented control group. The counts of lactic acid bacteria in ileal digesta were lower $(\mathrm{P}<0.05)$ in birds supplemented with lactose. No difference between the dietary treatments was observed regarding the population of intestinal coliform bacteria.
\end{abstract}

KEY WORDS: $\beta$-glucan, inulin, lactose, performance, ileal microbiota, chickens

\section{INTRODUCTION}

Questioning the use of antibiotic growth promoters (AGP) in animal production has resulted in withdrawal of these feed additives in the EU. Consequently, interest in feed additives that may act as alternatives for AGPs is growing. These additives include mixtures of organic acids, prebiotics, probiotics, symbiotics, and feed enzymes.

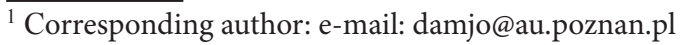


Prebiotics are generally classified as indigestible feed agents that are potentially beneficial to the health of the host due to their fermentable properties that may stimulate the growth and/or activity of bacteria in the ileum and caecum (Gibson and Roberfroid, 1995). According to this definition, prebiotics might include a very variable and wide range of chemical substances. However, mostly they are carbohydrates that are not hydrolysed by endogenous host enzymes, thus being available for microbiological fermentation in the lower parts of the non-ruminant gastrointestinal tract. Non-digestible oligosaccharides, especially those containing xylose, fructose, galactose, mannose and glucose, have attracted much attention and seem to be promising (Gibson and Roberfroid, 1995). The prebiotic properties of glycooligosaccharides, trans-galactooligosaccharides, glucooligosaccharides, lactulose, maltooligosac-charides, xylo-oligosaccharides, stachyose, raffinose, and sucrose thermal oligosaccharides have also been investigated (Patterson and Burkholder, 2003). Further, some structural carbohydrate components of NSP have been used in broiler chicken diets, and have been studied as potential prebiotics. Besides its effect on microbial fermentation, $\beta$-glucan has been shown to modulate immunity by increasing the activity of mammalian macrophages in vitro (Kataoka et al., 2002) and protecting broilers against Salmonella (Lowry et al., 2005).

It has been suggested that the major effect of prebiotics includes selective growth of lactic acid-producing bacteria, resulting in an increased concentration of shortchain fatty acids (SCFA), i.e. acetate, propionate, butyrate. High fermentation activity and high concentration of the SCFA in chicken caeca is correlated with a lower $\mathrm{pH}$ (Józefiak et al., 2004). This may inhibit some pathogenic bacteria by dissipating the proton motive force across the bacterial cell membrane (Russell, 1992).

The objective of the experiment was to study the influence of lactose, inulin and modified $\beta$-glucan as additives to a maize-based diet on the performance of broiler chickens as well as the $\mathrm{pH}$ in the crop, gizzard, ileum, caeca and populations of ileal microflora.

\section{MATERIAL AND METHODS}

A total of 384 male broiler chickens (Cobb 500) were included in a feeding experiment. The study design consisted of four dietary treatments, 12 replicates of 8 birds in each. Over the entire experimental period (day 1 - day 42), the birds were offered maize-based diets, in the starter period (days 1-14) and in the grower period (days 15-42). Diets contained no antibiotic growth promoters, but an ionophore coccidiostat (Lasalocid) was used (Table 1). The concentration of dry matter, crude protein and crude fat, ash and mineral content in the raw materials was determined using the AOAC procedure (2005). The first group (C) received a non-supplemented control diet, the second group (G), a diet 
Table 1. Composition and nutritional value of diets fed from 1 to 14 day and from 15 to 35 day

\begin{tabular}{lcc}
\hline Item & Days 0-14 & Days 15-42 \\
\hline Ingredients & & \\
maize & 48.55 & 58.3 \\
soyabean meal, 43\% & 40.0 & 31.5 \\
rapeseed oil & 6.6 & 5.7 \\
monocalcium phosphate & 1.6 & 1.5 \\
L-lysine, 20\% & 0.2 & 0.2 \\
DL-methionine, 20\% & 0.95 & 0.7 \\
NaCl & 0.3 & 0.3 \\
limestone & 0.7 & 0.7 \\
sodium carbonate & 0.1 & 0.1 \\
vitamin and mineral mix ${ }^{1}$ & 1.0 & 1.0 \\
& & \\
Calculated & 12.80 & 13.00 \\
ME in MJ/kg & 22.5 & 19.5 \\
crude protein & 1.30 & 1.07 \\
lysine & 0.54 & 0.45 \\
methionine & 0.99 & 0.95 \\
Ca & 0.44 & 0.40 \\
P available & &
\end{tabular}

supplemented with $0.025 \%$ modified $\beta$-glucan (Biolex Beta S), the third group (I), a diet supplemented with $0.3 \%$ inulin (Fructafit HD), and the fourth group, (L) a diet supplemented with $0.2 \%$ purified lactose. $\beta$-glucan and inulin were supplemented in accordance with the producers' recommendations, while the lactose level was chosen according to our earlier studies (unpublished). Feed intake and body weight were registered at weekly intervals, and the feed conversion ratio (FCR) and body weight gain (BWG) were calculated.

During two days in the sixth week of the experiment, 21 chickens from each group were sacrificed by cervical dislocation. The contents of the crop, gizzard, ileum and caeca were quantitatively collected and randomly pooled into seven replicates, each containing digesta from three birds. The ileum was defined as the small intestinal segment caudal to Meckel's diverticulum. The $\mathrm{pH}$ in the contents of all gastrointestinal segments was measured with a combined glass/reference electrode (CP-40 Elmetron, Poland). Diluted ileal digesta for counting microflora was further homogenized for $2 \mathrm{~min}$ in $\mathrm{CO}_{2}$-flushed plastic bags using a stomacher homogenizer (Interscience, France). Subsequently, the samples were serially diluted in 10 steps using pre-reduced salt medium according to the technique of Miller and Wolin (1974). Lactic acid bacteria were counted on de Man Rogosa and Sharp agar (Merck 1.10660, Darmstad, Germany) after anaerobic incubation 
at $39^{\circ} \mathrm{C}$ for two days. Coliform bacteria were enumerated on MacConkey agar (Merck 1.05465) after aerobic incubation at $39^{\circ} \mathrm{C}$ for one day.

The obtained results were analysed using the statistical software package SAS (1996), SAS ${ }^{\circ / S T A T}$. The results were subjected to one-way analysis of variance (ANOVA) followed by Duncan's multiple-range test. Statistical significance was established at $\mathrm{P}<0.05$.

\section{RESULTS AND DISCUSSION}

In general, the selected prebiotics did not improve the final performance of broiler chickens (Table 2). Terada et al. (1994) also reported that the application of oligosaccharides did not improve the performance of broilers. In the present experiment, however, in the starter period, all groups fed diets supplemented with prebiotics had a higher BWG in comparison with the control group. Irrespective of the diet, there were no changes in $\mathrm{pH}$ value in the crop and ileal chyme. However, in gizzard chyme, the $\mathrm{pH}$ was lower when birds were fed diets supplemented with prebiotics as compared with the control and was significantly lower $(\mathrm{P} \leq 0.05)$ in groups I and L (Table 2). Only the supplementation with inulin and lactose

Table 2. Performance of broiler chickens, $\mathrm{pH}$ and bacterial counts in ileal digesta

\begin{tabular}{|c|c|c|c|c|c|}
\hline \multirow{2}{*}{ Item } & \multicolumn{5}{|c|}{ Dietary treatments } \\
\hline & Control (C) & $\beta$-glucan $(\mathrm{G})$ & inuline $(\mathrm{I})$ & lactose $(\mathrm{L})$ & SEM \\
\hline \multicolumn{6}{|c|}{ Body weight gain, $g$} \\
\hline $0-14$ day & $281^{\mathrm{b}}$ & $287^{\mathrm{a}}$ & $287^{\mathrm{a}}$ & $300^{\mathrm{a}}$ & 0.004 \\
\hline 15 - 42 day & $1948^{\mathrm{a}}$ & $1858^{\mathrm{b}}$ & $1836^{\mathrm{b}}$ & $1838^{b}$ & 0.037 \\
\hline 0 - 42 day & $2229^{a}$ & $2146^{\mathrm{b}}$ & $2122^{b}$ & $2133^{b}$ & 0.031 \\
\hline \multicolumn{6}{|c|}{ Feed conversion ratio, $\mathrm{kg}$ feed $/ \mathrm{kg} B W G$} \\
\hline $0-14$ day & $1.66^{\mathrm{b}}$ & $1.64^{\mathrm{b}}$ & $1.76^{\mathrm{a}}$ & $1.60^{\mathrm{b}}$ & 0.012 \\
\hline 15 - 42 day & $1.98^{\mathrm{b}}$ & $2.00^{\mathrm{b}}$ & $2.29^{\mathrm{a}}$ & $2.04^{\mathrm{b}}$ & 0.018 \\
\hline 0 - 42 day & $1.94^{\mathrm{b}}$ & $1.95^{\mathrm{b}}$ & $2.22^{\mathrm{a}}$ & $1.98^{\mathrm{b}}$ & 0.016 \\
\hline \multicolumn{6}{|l|}{ pH of digesta } \\
\hline crop & 4.82 & 4.90 & 4.87 & 4.82 & 0.063 \\
\hline gizzard & $4.10^{\mathrm{a}}$ & $3.87^{\mathrm{ab}}$ & $3.65^{\mathrm{b}}$ & $3.69^{\mathrm{b}}$ & 0.072 \\
\hline ileum & 5.80 & 5.93 & 5.79 & 5.89 & 0.051 \\
\hline caeca & $6.58^{\mathrm{a}}$ & $6.58^{\mathrm{a}}$ & $6.12^{\mathrm{b}}$ & $6.31^{\mathrm{b}}$ & 0.083 \\
\hline \multicolumn{6}{|c|}{ Lactic acid bacteria log $c f u \times g^{-1}$ wet digesta } \\
\hline ileum & $8.5^{\mathrm{a}}$ & $8.7^{\mathrm{a}}$ & $9.0^{\mathrm{a}}$ & $8.2^{\mathrm{b}}$ & 0.178 \\
\hline \multicolumn{6}{|c|}{ Coliform bacteria log $c f u \times g^{-1}$ wet digesta } \\
\hline ileum & 4.9 & 4.0 & 4.9 & 5.0 & 0.159 \\
\hline
\end{tabular}


lowered the $\mathrm{pH}$ in the caeca of broiler chickens, which is in agreement with the definition of a prebiotic as suggested by Gibson and Roberfroid (1995).

Patterson and Burkholder (2003) reported that the positive effect of prebiotics becomes most apparent under poor environmental conditions where the birds are exposed to pathogenic microflora. It was reported that bacteria which inhabit the poultry GIT, Lactobacillus spp. (Grill et al., 1995) or Bifidobacterium spp. (Grill et al., 2000), deconjugate bile salts. It is well documented that deconjugated bile salts lose their emulsifying properties, resulting in decreased fat digestibility. In addition to potential energy loses, increased competition between the host and the microflora for nutrients may appear. In the present trial, feeding prebiotics, particularly inulin, impaired feed utilization and this could be explained by lower fat digestibility and/or other nutrient availability caused by activity of native microflora.

The caecum in broiler chickens is the main fermentative chamber and, in comparison with other gastrointestinal tract (GIT) segments, contains the largest number of bacteria (Józefiak et al., 2004). Thus, the ability of microbiota to ferment carbohydrates there is very high. In the present study, the $\mathrm{pH}$ of caecal digesta was lower in birds provided diets with inulin and lactose. Also Corrier et al. (1991), who provided 2.5\% lactose in drinking water, and Tellez et al. (1993), who administrated $10 \%$ of lactose in feed, reported a lowered $\mathrm{pH}$ in the caecal contents of broilers.

The intestinal colonization of different bacteria populations interacting with each other, as well as with the host, is correlated with the growth performance of the bird. In the present experiment, the number of lactic acid bacteria in the ileal content tended to be higher in groups fed diets supplemented with $\beta$-glucan and inulin as compared with the control group, whereas in the group fed the diet with lactose, the LAB counts were lower $(\mathrm{P}<0.05$; Table 2$)$. The used feed additives had no influence on the population of coliform bacteria. More distinct effects on the intestinal microbiota would be expected in the caecum, which is indicated by the marked changes in $\mathrm{pH}$ observed in caecal content (Table 2). However, the growth-depressing and potentially pathogenic bacteria can influence absorption processes more strongly in the ileum. Even though this region of the GIT is less colonized than the caecum, the competition of bacteria with the host can exert the most important effects on performance. It is therefore suggested that potential alternatives, similar to AGPs, should also affect this part of the GIT.

The results of the present experiment strongly question the effectiveness of the tested additives as potential growth-promoting agents in broiler chicken production. 


\section{REFERENCES}

AOAC, 2005. Association of Official Analytical Chemists, Official Methods of Analysis. 18th Edition. Arlington, VA

Corrier D. E., Hargis B., Hinton A., Lindsey Jr.D., Caldwell D., Manning J., DeLoach J. R., 1991. Effect of anaerobic cecal microflora and dietary lactose on colonization resistance of layer chicks to invasive Salmonella enteritidis. Avian Dis. 35, 337-343

Gibson G.R., Roberfroid M.B., 1995 Dietary modulation of the human colonic microbiota: introducing the concept of prebiotics. J. Nutr. 125, 1401-1412

Gong J., Forster R.J., Yu H., Chambers J.R., Wheatcroft R., Sabour P.M., Chen S., 2002. Molecular analysis of bacterial populations in the ileum of broiler chickens and comparison with bacteria in the cecum. FEMS Microbiol. Ecol. 41, 171-179

Grill J.P., Perrin S., Schneider F., 2000. Bile toxicity to some bifidobacteria strains: role of conjugated bile salt hydrolase and $\mathrm{pH}$. Can. J. Microbiol. 46, 878-884

Grill J.P., Schneider F., Crociani J., Ballongue J., 1995. Purification and characterization of conjugated bile salt hydrolase from Bifidobacterium longum BB536. Appl. Environ. Microbiol. $61,2577-2582$

Józefiak D., Rutkowski A., Scott M., 2004. Carbohydrate fermentation in the avian ceca - A review. Anim. Feed Sci. Tech. 113-115

Kataoka K., Mutta T., Yamazaki S., Takeshige K., 2002. Activation of macrophages by linear (13)- $\beta$-glucans. Implications for the recognition of fungi by innate immunity. J. Biol. Chem. 277, 36825-36831

Lowry V.K., Farnell M.B., Ferro P.J., Swaggerty C.L., Bahl A., Kogut M.H., 2005. Purified $\beta$-glucan as an abiotic feed additive up-regulates the innate immune response in immature chickens against Salmonella enterica serovar Enteritidis. Int. J. Food Microbiol. 98, 309-318

Miller T.L., Wolin M.J., 1974. A serum bottle modification of the Hungate technique for cultivating obligate anaerobes. Appl. Microbiol. 27, 985-987

Patterson J.A., Burkholder K.M., 2003. Application of prebiotics and probiotics in poultry production. Poultry Sci. 82, 627-631

Russell J.B., 1992. Another explanation for the toxicity of fermentation acids at low pH: anion accumulation versus uncoupling. J. Appl. Bacteriol. 73, 363-370

SAS, 1996. SAS ${ }^{\circledR}$ User's Guide: Statistics. SAS Institute Inc. Cary, NC

Tellez G., Corrier D.E., Deloach J.R., Jaeger L., Hargis B.M., 1993. Effect of dietary lactose on cecal morphology, $\mathrm{pH}$, organic acids, and Salmonella enteritidis organ invasion in Leghorn chicks. Poultry Sci. 72, 636-642

Terada A.H., Hera J., Sakamoto N., Sato S., Takagi T., Mitsuoka R., Mino K., Hara I., Fujimori T., 1994. Effects of dietary supplementation with lactosucrose (4G- $\beta$-D-galactosylsucrose) on fecal flora, cecal metabolites, and performance in broiler chickens. Poultry Sci. 73, 1663-1672 